\title{
RECONCILING CALIFORNIA'S PRE, POST, AND PER MORTEM RIGHTS OF PUBLICITY
}

\author{
Keenan C. Fennimore*
}

\section{INTRODUCTION}

In May 2010 the California legislature passed AB 585, an assembly bill extending the state's post mortem right of publicity to people whose identities have commercial value because of their death. ${ }^{1}$ The bill amended California Civil Code section 3344.1 , which previously protected only people whose identities had commercial value at the time of their death. ${ }^{2} \mathrm{AB} 585$ was proposed in response to the then-recent controversy surrounding the sale of $t$ shirts protesting the war in Iraq and featuring the names of American soldiers who died while serving there. ${ }^{3}$ The law now entitles families of deceased soldiers to compensation for such unauthorized commercial use. ${ }^{4}$ At least five other U.S. states statutorily recognize publicity rights for deceased soldiers; ${ }^{5}$ however, AB 585 was unique in that it extended protection to the non-military deceased as well. ${ }^{6}$

In general, the U.S. right of publicity is "the inherent right of every human being to control the commercial use of his or her identity." Although nearly two-thirds of all U.S. states recognize some form of publicity protection, either by statute or common law, ${ }^{8}$ a sufficient justification for how and why the law provides such a right remains in dispute. ${ }^{9}$ Despite some initial disinclination among courts and commentators toward categorizing the right of publicity, ${ }^{10}$ what was once considered only a proprietary interest in the

* J.D., 2012, Indiana University Robert H. McKinney School of Law; B.A., 2004, Indiana University.

1. 2010 Cal. Stat. ch. $20, \S 1$. (emphasis added) (codified at CAL. CIV. CoDE $\S 3344.1$ (h) (2011)).

2. CAL. Civ. CoDE $\S 3344.1$ (h) (2009) (emphasis added), amended by 2010 Cal. Stat. ch. $20, \S 1$.

3. 2009 Legis. B. Hist. Cal. A.B. 585 (Bill Analysis, Assembly Floor), May 3, 2010; see infra Part III.B.3.

4. CAL. Civ. CODE § 3344.1(h) (2011).

5. Arizona, ARIz. REV. STAT. $§ 13-3726$ (2009); Florida, FL. STAT. $\$ 540.08$ (2009); Louisiana, LA. REV. STAT. ANN. § 14:102:21 (2009); Oklahoma, OKLA. STAT. tit. 21, § 839.1A (2009); and Texas, Tex Bus. \& COM. CODE ANN. $§ 721.002$ (2009).

6. 2010 Cal. Stat. ch. $20, \S 1$ (defining "deceased personality" as "any natural person") (codified at CAL. CIV. CODE $\S 3344.1(\mathrm{~h})(2011)$ ).

7. $1 \mathrm{~J}$. Thomas McCarthy, The Rights of Publicity and Privacy $\S 1: 3$ (2d ed. 2010).

8. Id. § 6:3.

9. See infra Part IV.B; Mark P. McKenna, The Right of Publicity and Autonomous SelfDefinition, 67 U. PITT. L. REv. 225, 247 (2005).

10. See infra notes 173-76 and accompanying text. 
commercial value of identity is now widely regarded as a bona fide property right. ${ }^{11}$ As a result of this foundational shift, the right of publicity has been commonly justified post hoc by the traditional theories associated with property protection in the United States: labor theory, unjust enrichment, and economic incentives. ${ }^{12}$ These justifications have been met with postmodern criticism by some commentators, who have examined the cultural process by which commercial value in identity is created and have concluded that exclusive entitlement to this value is unwarranted and its rationale, unpersuasive. ${ }^{13}$

This Note argues that California's newly spawned per mortem ${ }^{14}$ right of publicity lacks even the weak property justifications asserted for its pre mortem ${ }^{15}$ and post mortem ${ }^{16}$ counterparts. ${ }^{17}$ As a legal remedy aimed at protecting personal interests, $\mathrm{AB} 585$ extended the state's statutory right of publicity regime beyond any formal property rationale and provided a new arena in which to revive the right's unsettled theoretical debate. ${ }^{18}$ This Note offers a comparative perspective of identity rights in the United States and Germany, ${ }^{19}$ and it suggests the concept of economic self-determination as a means of theoretically reconciling California's disparate statutes in the face of an incoherency that has plagued the property-based right of publicity in the United States for nearly three decades. ${ }^{20}$

Part II of this Note traces the history of common law identity appropriation claims in the United States, highlighting the right of publicity's emergence from the personal right of privacy and its evolution into a

11. See infra Part IV.A

12. See infra Part IV.B; 1 MCCARTHY, supra note 7, §§ 2:1, 2:6; Michael Madow, Private Ownership of Public Image: Popular Culture and Publicity Rights, 81 CALIF. L. REv. 125, 178 (1993). Protection from consumer deception is another rationale asserted for the U.S. right of publicity, which is not addressed in this Note. See id. at 228-38.

13. See infra Part IV.B; Madow, supra note 12, at 178-228; Alice Haemmerli, Whose Who? The Case for a Kantian Right of Publicity, 49 DukE L.J. 383, 430-41 (1999); McKenna, supra note 9, at 245-75; David Westfall \& David Landau, Publicity Rights as Property Rights, 23 CARDOZO ARTS \& ENT. L.J. 71, 117-23 (2005).

14. This Note uses the term "per mortem" to describe the right of publicity as established for identities with commercial value because of their death. To the author's knowledge, this prefix has never before been applied in the right of publicity context.

15. This Note uses the term "pre mortem" to easily identify the right of publicity in a living personality, as distinguished from that in deceased per and post mortem personalities. To the author's knowledge, this term has never before been applied in the right of publicity context. Pre mortem publicity rights are typically referred to by courts and commentators as the general "right of publicity."

16. This Note uses the term "post mortem" to describe the right of publicity as recognized for identities with commercial value at the time of their death. This term is commonly applied in the right of publicity context by courts and commentators.

17. See infra Part III.A.

18. See infra Part. III B.

19. See infra Parts III, V.

20. See infra Part IV. 
commercial property right. Part III examines the social motivations behind California's three-piece, statutory right of publicity regime and the practical effect of its per mortem right in light of the commercial value requirement of publicity protection. Part IV analyzes per mortem publicity rights according to the traditional justifications and modern critiques of the publicity-as-property model. Part $V$ provides a basic overview of German personality rights and the autonomy theory that underlies their protection. This Part also highlights the functional application of economic self-determination by German courts. Part VI offers a brief comparative perspective of autonomy-based law in Germany and the United States and identifies a potential source of compatibility for personality-based identity protection in California.

\section{IDENTITY APPROPRIATION IN THE UNITED STATES}

In order to appreciate California's statutory contradiction, it is important first to examine generally the U.S. right of publicity's origins in privacy law, its evolution into a pure property right, and several resulting distinctions between privacy and publicity as they relate to California's addition of a per mortem statute.

\section{A. The Right of Privacy}

The right of privacy was first conceptualized in 1890 by Samuel Warren and Louis Brandeis. ${ }^{21}$ Concerned by the rising practice of gossip journalism in the United States and the technological innovations that afforded it, ${ }^{22}$ Warren and Brandeis sought to extract from existing case law an independent claim against the unauthorized publication of private facts and photographs, for which the law at time offered no protection. ${ }^{23}$ As published in their seminal article, The Right to Privacy, Warren and Brandeis found a remedy, primarily in the law of copyright, by extending authorial control of intentional creations to the incidental. ${ }^{24}$ Their proposed "right to privacy" was aimed famously at protecting "the right to enjoy life" and "the right to be let alone.,"25

\section{Protection of Emotional Interests}

Despite wide scholastic recognition of The Right to Privacy, the alleged

21. McKenna, supra note 9, at 234; see Samuel D. Warren \& Louis D. Brandeis, The Right to Privacy, 4 HARV. L. REV. 193 (1890).

22. Warren \& Brandeis, supra note 21, at 195. "Instantaneous photographs and newspaper enterprise have invaded the sacred precincts of private and domestic life; and numerous mechanical devices threaten to make good the prediction that 'what is whispered in the closet shall be proclaimed from the house-tops." Id.

23. McKenna, supra note 9, at 234; Warren \& Brandeis, supra note 21, at 197.

24. McKenna, supra note 9, at 234; Warren \& Brandeis, supra note 21, at 198-200.

25. Warren \& Brandeis, supra note 21, at 193. 
right lost its first battle in court. ${ }^{26}$ In Roberson v. Rochester Folding Box Co., a young girl named Abigail Roberson sought an injunction against and compensation for emotional injuries caused by a milling company's use of her likeness to promote the sale of flour without her consent. ${ }^{27}$ The Franklin Mills Company published prints featuring Roberson's image encircled by the company's name and slogan, ${ }^{28}$ and when Roberson was recognized by others in public, she was scoffed at and jeered, resulting in her mental anguish. ${ }^{29}$

Although acknowledging Warren and Brandeis's "clever article,"30 the New York Court of Appeals rejected Roberson's pioneering privacy claim. ${ }^{31}$ The court majority concluded that the right of privacy had not yet received recognition at law $^{32}$ and that such recognition was a concern for the state legislature. ${ }^{33}$ Further, the majority emphasized that the law protects people's body, reputation, and property but not their "peace of mind," "feelings," or "happiness." 34 Four dissenting judges, however, embraced the Warren and Brandeis article, finding the right of privacy to be the complement of everyone's longstanding right to an inviolate person. ${ }^{35}$ These dissenters dismissed the absence of exact precedent in favor of equity, ${ }^{36}$ whether the remedy was to be found in an analogical extension of common-law principles or the application of natural justice. ${ }^{37}$

Three years after Roberson, the right of privacy received its first recognition at common law. ${ }^{38}$ In Pavesich v. New England Life Ins. Co., a man named Paolo Pavesich brought suit against the New England Mutual Life Insurance Company for the emotional damages he suffered as a result of the company's unauthorized use of his recognizable image in a newspaper

26. See Roberson v. Rochester Folding Box Co., 64 N.E. 442 (N.Y. 1902).

27. Id. at 442 .

28. Id.

29. Id. Roberson alleged that she was "greatly humiliated ... causing her great distress and suffering both in body and mind; that she was made sick and suffered a severe nervous shock, was confined to her bed and compelled to employ a physician," resulting in $\$ 15,000$ in damages. Id.

30. Id. at 444.

31. Id. at 447.

32. Id.

33. Id. at $443,447$.

34. $I d$. at 446 .

35. Id. at 449 .

36. Id. at 451 . "It would be ... an extraordinary view which, while conceding the right of a person to be protected against the unauthorized circulation of an unpublished lecture, letter, drawing, or other ideal property, yet, would deny the same protection to a person, whose portrait was unauthorizedly obtained, and made use of, for commercial purposes." Id.

37. Id. at 449. "It would be a reproach to equitable jurisprudence, if equity were powerless . . . in remedying a wrong, which, in the progress of civilization, has been made possible as the result of new social, or commercial conditions." Id.

38. 1 MCCARTHY, supra note $7, \S 1: 17$; see Pavesich v. New England Life Ins. Co., 50 S.E. 68 (Ga. 1905). 
advertisement. ${ }^{39}$ The advertisement depicted Pavesich and attributed to him several lines of text endorsing New England Mutual and praising his use of the company's services. ${ }^{40}$ Pavesich, who had never used the company's services and had never made any such statements, found the use of his image offensive and successfully sued the company for invasion of privacy. ${ }^{41}$ The Supreme Court of Georgia adopted the Roberson dissenting opinion in its entirety, ${ }^{42}$ establishing the common law right of privacy as the personal right of every individual "to be let alone."43

As privacy law developed across the United States, not all people found themselves within the ambit of its protection. Specifically, celebrity plaintiffs found it difficult to recover for the unauthorized appropriation of their names and likenesses because of the right's emotional focus. ${ }^{44}$ In one famous case, ${ }^{45}$ O'Brien v. Pabst Sales Co., the United States Court of Appeals for the Fifth Circuit rejected an invasion of privacy claim brought by a professional football player named Davey $\mathrm{O}^{\prime}$ Brien. ${ }^{46}$ The well-known player sought damages from a distributor of "Pabst Famous Blue Ribbon Beer" for the company's use of his photograph in its advertising calendar. ${ }^{47} \mathrm{O}^{\prime}$ Brien argued that he suffered damage to his name by its commercial association with beer ${ }^{48}$ and that the advertisement falsely indicated that he endorsed the company's product. ${ }^{49}$ The court concluded, however, that the publicity O'Brien received "was only that which he had been constantly seeking and receiving" as a public figure. ${ }^{50}$ Because O'Brien was not a "private person," he had no claim for invasion of the right of privacy. ${ }^{51}$

39. Pavesich, 50 S.E. at 68.

40. Id. at 68-69. The text of the advertisement read, "In my healthy and productive period of life I bought insurance in the New England Mutual Life Insurance Co., of Boston, Mass., and to-day my family is protected and I am drawing an annual dividend on my paid-up policies." $I d$. at 69 .

41. Id.

42. Id. at 78 (quoting Roberson 64 N.E. at 448-51).

43. Id. (quoting Roberson, 64 N.E. at 449). Accord Melvin v. Reid, 297 P. 91,92 (Cal. Dist. Ct. App. 1931).

44. 1 MCCARTHY, supra note $7, \S 1: 25$.

45. Id.

46. O'Brien v. Pabst Sales Co., 125 F.2d 167, 168, 170 (5th Cir. 1941).

47. Id. at 168 .

48. Id. at 170. The athlete testified "that he was a member of the Allied Youth of America, the main theme of which was the diong [sic] away with alcohol among young people; that he had had opportunities to sell his endorsement for beer ... and had refused it; and that he was greatly embarrassed and humiliated when he saw the calendar and realized that his face and name was associated with publicity for the sale of beer." Id. at 168-69.

49. Id. at 170 .

50. Id. The athlete was "perhaps the most publicized football player of the year 1938-39." Id. at 169.

51. Id. at 170. Accord Cohen v. Marx, 211 P.2d 320, 321 (Cal. Dist. Ct. App. 1949). 


\section{Privacy's Inalienability}

Privacy's inalienability was another challenge that celebrities faced as a result of the right's emotional focus. In Hanna Mfg. Co. v. Hillerich \& Bradsby Co., a longtime baseball bat manufacturer, Hillerich \& Bradsby, sought to enjoin a newcomer to the business, Hanna Manufacturing, from imprinting bats with the names of famous baseball players. ${ }^{52}$ Because Hillerich \& Bradsby maintained exclusive contracts with many players for the use of their names, autographs, and photographs in connection with the sale of baseball bats, the company argued that the players had assigned to it their property rights in their names. ${ }^{53}$ The United States Court of Appeals for the Fifth Circuit, however, denied the manufacturer's injunction. ${ }^{54}$ Finding the contracts simply to be a waiver of the players' right of privacy rather than an assignment of that right to Hillerich \& Bradsby, the court emphatically stated, "Fame is not merchandise. It would help neither sportsmanship nor business to uphold the sale of a famous name to the highest bidder as property." 55

\section{Privacy's Terminability}

The personal, emotional nature of the right of privacy also rendered it incapable of surviving the death of the right's holder. In Jesse James, Jr. v. Screen Gems Inc., the wife of Jesse James, Jr., son of the infamous outlaw Jesse James, sought compensation from a production company for its commercial exploitation of her deceased husband's name and personality in a biographical film titled, Bitter Heritage ${ }^{56}$ By her designation as "Mrs. Jesse James, Jr.," the wife claimed an interest in her deceased husband's right of privacy. ${ }^{57}$ Yet, the court found the alleged wrong to be directed toward the decedent, not his wife, and therefore, concluded the facts of her complaint to be insufficient to constitute an invasion of privacy. ${ }^{58}$ The wife's asserted cause of action for an invasion of privacy was personal to Jesse James, Jr. and was not capable of surviving his death. ${ }^{59}$

52. Hanna Mfg. Co. v. Hillerich \& Bradsby Co., 78 F.2d 763, 763-64 (5th Cir. 1935).

53. Id. at $764,765-66$.

54. Id. at 768 .

55. Id. at 766-67. Accord Strickler v. Nat'l Broadcasting Co., 167 F. Supp. 68 (S.D. Cal. 1958).

56. Jesse James, Jr. v. Screen Gems, Inc., 344 P.2d 799, 800 (Cal. Ct. App. 1959). The wife also claimed personally to have suffered emotional injuries as a result of the film. Id. at 799-800.

57. Id. at 800 .

58. Id. at 801 .

59. Lugosi v. Universal Pictures, 603 P.2d 425, 430 (Cal. 1979) (discussing Jesse James, $J r ., 344$ P.2d 799). "When the right invaded was more strictly the privilege 'to be let alone,' the courts in this state have refused to extend to the heirs of the (potential) plaintiff the right to recover for the invasion of that right: 'It is well settled that the right of privacy is purely a personal one; it cannot be asserted by anyone other than the person whose privacy has been 


\section{B. The Right of Publicity}

Celebrity struggles to recovery under claims for invasion of privacy by commercial appropriation, magnified by the rise of celebrity culture in the United States, ${ }^{60}$ set the stage for the evolution of property-based publicity protection. ${ }^{61}$ In this light, it has been stated that "[ $[$ t]he right of publicity was created not so much from the right of privacy as from frustration with it." ${ }^{\prime 62}$

\section{Protection of Economic Interests}

Fifteen years after Hanna Manufacturing struck out in the Fifth Circuit, and on an almost identical set of facts, the United States Court of Appeals for the Second Circuit explicitly rejected the holding of that case and gave life to the common law right of publicity. ${ }^{63}$ In Haelan Laboratories, Inc. v. Topps Chewing Gum, Inc., rival chewing gum manufacturers were competing for the rights to use baseball players' names and photographs on baseball cards. ${ }^{64}$ Haelan Laboratories had exclusive agreements with certain players whose names and photographs were used by Topps Chewing Gum without Haelan's authorization. ${ }^{65}$ Topps claimed that privacy was a personal and non-assignable right and that Haelan merely retained a waiver of the players' rights of privacy ${ }^{66}$ In rejecting this defense, the court concluded that, "in addition to and independent of th[e] right of privacy ... a man has a right in the publicity value of his photograph . . . This right might be called a 'right of publicity.",67

\section{Publicity's Alienability}

Although rightfully celebrated as the foundation of the property-based right of publicity, Haelan Laboratories, Inc. had the practical effect simply of making one's likeness alienable via assignment. ${ }^{68} \mathrm{As}$ such, the decision reflects an "eminently functionalist" approach to commercial identity appropriation. ${ }^{69}$ In establishing the right of publicity as protecting an entirely different interest from the right of privacy, one focusing uniquely on economic injury rather than

invaded, that is, plaintiff must plead and prove that his privacy has been invaded. Further, the right does not survive but dies with the person." Id. Accord Metter v. Los Angeles Examiner, 95 P.2d 491 (Cal. Dist. Ct. App. 1939).

60. Michael Madow offers a thorough account of the rise of celebrity culture in America. See Madow, supra note 12, at 147-67.

61. Id. at 167.

62. Id.

63. 1 MCCARTHY, supra note $7, \S 1: 26$.

64. Haelan Labs., Inc. v. Topps Chewing Gum, Inc., 202 F.2d 866, 867 (2d Cir. 1953).

65. Id.

66. Id.; see 1 MCCARTHY, supra note 7, $§ 1: 26$.

67. Haelan Labs., Inc., 202 F.2d at 868. Accord Motschenbacher v. R.J. Reynolds Tobacco Co., 498 F.2d 821 (9th Cir. 1974).

68. Westfall \& Landau, supra note 13, at 76-77.

69. Id. at 77 . 
hurt feelings and mental anguish, ${ }^{70}$ Judge Frank was merely responding to preexisting business practices. ${ }^{71}$ The judge explained:

[I]t is common knowledge that many prominent persons (especially actors and ball-players), far from having their feelings bruised through public exposure of their likenesses, would feel sorely deprived if they no longer received money for authorizing advertisements, popularizing their countenances, displayed in newspapers, magazines, busses, trains and subways. This right of publicity would usually yield them no money unless it could be made the subject of an exclusive grant which barred any other advertiser from using their pictures. ${ }^{72}$

\section{Publicity's Descendibility}

Despite its economic focus, the right of publicity's roots in privacy law made it difficult for some courts to shake the "personal" label. ${ }^{73}$ In Lugosi $v$. Universal Pictures, the Supreme Court of California rejected the notion that the right of publicity was descendible. ${ }^{74}$ The claimants in Lugosi were the heirs of actor Béla Lugosi, known for his role in the 1931 film, Dracula ${ }^{75}$ Lugosi's heirs brought suit against Universal Studios, the movie studio for which Lugosi had worked, seeking to recover profits made by the studio's licensing of the Lugosi's image, as the Dracula character, for merchandising purposes. ${ }^{76}$ The court recognized that Lugosi had a proprietary interest in his identity ${ }^{77}$ but ruled that this interest had not passed to Lugosi's heirs on his death. ${ }^{78}$ Problematically, ${ }^{79}$ the court concluded, "[T] he right to exploit name and likeness is personal to the artist and must be exercised, if at all, by him during his lifetime." 80

In dissent, Chief Justice Bird challenged the Lugosi majority's rejection

70. Ben C. Adams, Recent Development, Inheritability of the Right of Publicity Upon the Death of the Famous, 33 VAND. L. REV. 1251, 1252 (1980).

71. Westfall \& Landau, supra note 13, at 77-78. "[B]aseball card companies had been signing exclusive contracts with players for some time prior to the decision," and "[s]imilar practices were occurring in other areas of the entertainment industry." Id.

72. Haelan Labs., Inc., 202 F.2d at 868.

73. 1 MCCARTHY, supra note $7, \S 1: 32$.

74. Lugosi v. Universal Pictures, 603 P.2d 425, 431 (Cal. 1979).

75. Id. at $426-27$.

76. Id. at 427 .

77. Id. at 428 .

78. Id. at 427,431 (reversing the lower court's finding of a descendible right of publicity).

79. See infra Part III.B.2.

80. Lugosi, 603 P.2d at 431 (emphasis added). 
of a descendible right of publicity. ${ }^{81}$ Distinguishing the right of publicity's proprietary nature from the personal right of privacy, Chief Justice Bird found no persuasive policy that suggested the right of publicity "should not descend at death like any other intangible property right." ${ }^{, 82}$ This dissenting opinion "became the inspiration" for the enactment of California's statutory descendible right of publicity only five years later. ${ }^{83}$

\section{California AB 585 In Perspective}

California has maintained two statutory approaches to the right of publicity since $1984{ }^{84}$ The state's pre and post mortem statutes were developed as supplementary protection to its common law right of publicity, ${ }^{85}$ and they represent legislative responses to two similar sociolegal events. The enactment of $A B 585$ added a third approach - the per mortem right of publicity ${ }^{86}$ But the social motivations for California's per mortem protection and the statute's practical effect within the state's existing statutory regime reveal $A B 585$ as a contradictory application of the publicity-as-property model.

\section{A. California's Statutory Regime}

California's pre mortem right of publicity statute is codified in section 3344 of the California Civil Code. ${ }^{87}$ The state's post mortem statute, originally enacted as section $990{ }^{88}$ is found in section $3344.1 .^{89}$ This section also provides for California's per mortem right of publicity, as established by $\mathrm{AB}$ $585 .^{90}$

\section{Pre Mortem Protection}

Section 3344 was legislated in response to a complaint about computergenerated solicitation letters mailed by Reader's Digest to a series of

81. Id. at 434 (Bird, C.J., dissenting).

82. Id. at 445-46 (Bird, C.J., dissenting) (quoting Factors Etc. Inc. v. Creative Card Co., 444 F. Supp. 279, 284 (S.D.N.Y. 1977)).

83. Steven Andreacola, Trademark's Neighbors: History of California Civil Code 3344.1, 12 J. CONTEMP. LEGAL ISSUES 592, 594 (2001).

84. 1 MCCARTHY, supra note 7, § 6:24; see 1971 Cal. Stat. ch. 1595, § 1 (enacting pre mortem statute); see also 1984 Cal. Stat. ch. 1704, $\$ 1$ (enacting post mortem statute).

85. See Comedy III Prods., Inc. v. Gary Saderup, Inc., 21 P.3d 797, 799 (Cal. 2001) (citing Lugosi, 603 P.2d at 428 n.6).

86. See supra note 14.

87. CAL. CIV. CODE $\S 3344$ (2011).

88. 1984 Cal. Stat. ch. 1704, § 1; CAL. CIV. CoDE $\S 990$ (1988), renumbered by 1999 Cal. Stat. ch. $998, \S 1$.

89. CAL. CIV. CODE $\S 3344.1$ (2011).

90. See 2010 Cal. Stat. ch. $20, \S 1$. 
neighboring individuals. ${ }^{91}$ Each form letter stated that its recipient and his or her neighbor had been selected as sweepstakes contestants by the magazine. ${ }^{92}$ The neighbor was identified by name, and each recipient was named as a "neighbor" in solicitation of another resident in the neighborhood. ${ }^{93}$ In an ensuing lawsuit, Stilson v. Reader's Digest Assn., Inc., the neighbors complained that these letters were a misappropriation of their names to sell magazine subscriptions in violation of their rights to privacy. ${ }^{94}$ In order to recover damages, however, California's privacy law required each recipient to prove mental suffering, a burden that ultimately defeated the neighbors' certification as a class. ${ }^{95}$

In response to and during this litigation, the California legislature added section 3344 to the state's Civil Code. ${ }^{96}$ The statute was designed to resolve the neighbors' need to prove damages by providing a minimum statutory recovery of $\$ 300^{97}$ for any invasion of privacy by commercial appropriation. ${ }^{98}$ As originally enacted in $1971,{ }^{99}$ California's pre mortem right of publicity statute provided:

Any person who knowingly uses another's name, photograph, or likeness, in any manner, for purposes of advertising products, merchandise, goods or services, or for purposes of solicitation of purchases of products, merchandise, goods or services, without such person's prior consent ... shall be liable for any damages sustained by the person or persons injured as a result thereof. In addition, in any action brought under this section, the person who violated the section shall be liable to the injured party or parties in an amount no less than three hundred dollars $(\$ 300) .{ }^{100}$

Judgment was issued against the recipients in Stilson with no discussion

91. 1 MCCARTHY, supra note 7, § 6:23 (citing Jerome E. Weinstein, Commercial Appropriation of Name or Likeness: Section 3344 and the Common Law, 52 L.A.B.J. 430, 432 (1977)); Stilson v. Reader's Digest Assn., Inc., 28 Cal. App. 3d 270, 272 (1972).

92. 1 MCCARTHY, supra note 7, § 6:23; Stilson, 28 Cal. App. 3d at 272.

93. 1 MCCARTHY, supra note $7, \S 6: 23$; Stilson, 28 Cal. App. 3d at 272.

94. Stilson, 28 Cal. App. 3d at 273.

95. Id. at 273-74.

96. 1971 Cal. Stat. ch. $1595, \S 1$ (now codified at CAL. CIV. CoDE 3344.1 (2011)).

97. In 1984 the statutory minimum recovery was raised to $\$ 750.1984 \mathrm{Cal}$. Stat. ch. 1704 , § 2 (now codified at CAL. CIV. CODE $\S 3344(a)$ (2011)).

98. 1 MCCARTHY, supra note 7, at $\S 6: 23$. "The use is without the consent of such persons, and, unless their name has an ascertainable commercial value, they are without effective legal remedy." Id. § 6:23 n.6 (quoting Summary of Legislation, AB 826, at 3 (1971)).

99. 1971 Cal. Stat. ch. $1595, \S 1$.

100. CAL. Civ. CodE $§ 3344$ (a) (1972); see Weinstein, supra note 91, at 433 n.17. 
of section $3344 .{ }^{101}$ But as a known catalyst for the statute, the case's underlying facts illustrate that California's pre mortem right of publicity was initially motivated by emotion-based, privacy concerns rather than proprietary interests in commercial value. ${ }^{102}$ Although the broad language of section 3344 seemed to allow for the inclusion of both types of identity protection, ${ }^{103}$ Chief Justice Bird prompted a narrower reading of the statute in his Lugosi dissent:

The legislative history of section 3344 strongly suggests that the Legislature was concerned with an individual's right to privacy, not an individual's proprietary interest in his or her name and likeness ..... In contrast to these numerous references to the right of privacy, there is no mention in the legislative documents of the right of publicity or the economic interest protected thereunder. ${ }^{104}$

In 1985 the California legislature passed the Celebrity Rights Act, amending section 3344 to provide for the additional recovery of "any profits from the unauthorized use that are attributable to the use and are not taken into account in computing the actual damages." 105 In contrast to the privacy motives of the original statute's enactment, the language added by the amendment evokes the economic focus of the now-recognized right of publicity. ${ }^{106}$ The California Court of Appeals has since clarified that the statutory minimum can only be recovered as a measure of damages for mental distress, ${ }^{107}$ while a defendant's "attributable" profits are only recoverable for injury to the commercial value of identity. ${ }^{108}$ Section 3344 therefore provides hybrid privacy-publicity protection for commercial appropriation of identity. ${ }^{109}$ The nature of the right asserted under the pre mortem statute-privacy or publicity-depends on the type of damages a claimant seeks.

\section{Post Mortem Protection}

In addition to its pre mortem amendments, the Celebrity Rights Act also

101. 1 MCCARTHY, supra note $7, \S 6: 23$.

102. Id.

103. Id. ("Recoverable damages under the statute included both kinds of injury within the phrase 'shall be liable for any damages sustained by the person or persons injured as a result thereof."').

104. Lugosi v. Universal Pictures, 603 P.2d 425, 442 (Cal. 1979) (Bird, C.J., dissenting).

105. 1984 Cal. Stat ch. $1704, \S 1$ (emphasis added) (now codified at CaL. Crv. CoDE $\S$ 3344(a) (2011)).

106. 1 MCCARTHY, supra note $7, \S 6: 23$.

107. Miller v. Collectors Universe, Inc. 159 Cal. App. 4th 988, 1006 (2008); see 1 MCCARTHY, supra note 7, § 6:46.

108. 1 MCCARTHY, supra note $7, \S 6: 46$.

109. Baugh v. CBS, Inc., 828 F.Supp. 745, 753 (N.D. Cal. 1993). 
enacted California Civil Code section 990 (now section 3344.1) ${ }^{110}$ which established post mortem publicity protection for deceased personalities. ${ }^{111}$ Section 3344.1 provides remedies for infringement that are similar to California's pre mortem statute. ${ }^{112}$ However, unlike the hybrid protection offered by section 3344 , section 3344.1 is solely concerned with a person's proprietary interest in the commercial value of identity. ${ }^{113}$ Subsection (b) clearly provides, "The rights recognized under this section are property rights, freely transferable or descendible . ...",114

It is widely accepted that California Civil Code section 990 was enacted to legislatively overrule the California Supreme Court's holding in Lugosi, ${ }^{115}$ that California's common law right of publicity was not descendible. ${ }^{116}$ Inspired by Chief Justice Bird's dissenting opinion, lobbied for by the Screen Actors Guild, and supported by numerous celebrities and celebrity heirs, ${ }^{117}$ section 990 (now section 3344.1) established a claim for the successors-in-interest of "deceased personalities," "118 meaning people whose identities had commercial value at the time of their death. ${ }^{19}$

\section{Per Mortem Protection}

Unlike like with its pre and post mortem statutes, the California legislature went beyond state lines to find its motivation for establishing per mortem protection. AB 585 was proposed in response to nationwide controversy surrounding an Arizona peace activist named Dan Frazier. ${ }^{120}$ Frazier owns and operates a website ${ }^{121}$ from which he sells merchandise expressing various political views, including several disputed anti-war t-

110. 1984 Cal. Stat. ch. $1704, \S 1$; CAL. Crv. CODE $\S 990$ (1988), renumbered by 1999 Cal. Stat. ch. 998, § 1 (now codified at CAL. Crv. CoDE $\$ 3344.1$ (2011)).

111. CAL. CIV. CoDE $\S 3344.1$ (a) (2009), amended by 2010 Cal. Stat. ch. 20, § 1. "Any person who uses a deceased personality's name, voice, signature, photograph, or likeness, in any manner, on or in products, merchandise, or goods, or for purposes of advertising or selling, or soliciting purchases of, products, merchandise, goods, or services, without prior consent from the person or persons specified in subdivision (c), shall be liable for any damages sustained by the person or persons injured as a result thereof." $I d$.

112. Compare CaL. Civ. CODE $\S 3344.1$ (b) (2009), amended by 2010 Cal. Stat. ch. 20, § 1, with CAL. CIV. CODE $\S 3344$ (a) (2011).

113. See CAL. CIV. CODE § 3344.1(b) (2009), amended by 2010 Cal. Stat. ch. 20, § 1.

114. Id.

115. Andreacola, supra note 83 , at 593.

116. 1 MCCARTHY, supra note 7, § 6:24.

117. Andreacola, supra note 83 , at $593 \mathrm{n} .11$.

118. CAL. CIV. CODE $\S 990$ (b)-(d) (1988), renumbered by 1999 Cal. Stat. ch. 998, $§ 1$ (now codified at CAL. CIV. CODE $\S 3344.1$ (b)-(d) (2011)).

119. CAL. CIV. CODE $\S 990(\mathrm{~h})$ (1988) (emphasis added), renumbered by 1999 Cal. Stat. ch. 998, § 1 (now codified at CAL. CIV. CoDE $\S 3344.1(\mathrm{~h})$ (2011)).

120. 2009 Legis. B. Hist. Cal. A.B. 585 (Bill Analysis, Assembly Floor), May 3, 2010.

121. See CARRYABIGSTICKER, http://www.carryabigsticker.com/ (last visited Aug. 31, 2012). 
shirts. ${ }^{122}$ One specific t-shirt displays the words, "Bush Lied" and "They Died," printed over a background of the names of 3,461 deceased soldiers. ${ }^{123}$ Additional text on the shirt indicates that these names represent "U.S. troops who died in Iraq from March 20, 2003 to October 23, 2006." ${ }^{124}$

Throughout the United States, numerous family members of deceased soldiers publicly objected to Frazier's shirt, some threatening to sue Frazier if he did not cease and desist his use of the soldiers' names. ${ }^{125}$ Additionally, several Arizona families complained to the state legislature and governor in an effort to prevent future sales of the shirt. ${ }^{126}$ These complaints resulted in the enactment of an Arizona criminal statute ${ }^{127}$ that protects against knowing use of a deceased soldier's name or image for commercial purposes without the prior consent of the decedent's next of kin. ${ }^{128}$ Violators of this law are guilty of a Class 1 misdemeanor ${ }^{129}$ and subject to civil liability under Arizona's right of publicity statute. ${ }^{130}$

One of the asserted purposes for Arizona's deceased soldier statute is "to protect military families in mourning for their sons and daughters killed in the war." ${ }^{\text {"131 }}$ Similarly, the author of AB 585 described his motivation behind California's per mortem right of publicity amendment, stating, "[O]ut of respect to both the soldiers and their families, the names of fallen soldiers should not be exploited for commercial gain." "132 The California Senate's analysis of $\mathrm{AB} 585$ echoed this sentiment, adding, "[P]arents of soldiers who had been lost in the war in Iraq, state that 'exploitation because of death solely for monetary gain is reprehensible and in complete disregard for the parents' well-being." "133 These emotion-based statements stand in stark contrast to the economic motivations for the state's pre and post mortem statutes. And in this light, AB 585 misapplied California's publicity-as-property model in order to protect the personal interests of the deceased-interests that are fundamentally

122. Frazier v. Boomsma, 2007 U.S. Dist LEXIS 72427, *2 (D. Ariz. 2007).

123. Id. Two additional shirts containing different anti-war messages printed over these same names are also sold. $I d$. at *2-3.

124. $I d$. at $* 2$.

125. Id. at *5.

126. Id.

127. Id.

128. ARIZ. REV. STAT. § 13-3726(A) (2011).

129. Id. § 13-3726(D).

130. Id. $\S 13-3726$ (B) (incorporating ARIZ. REV. STAT. §12-761 (2010)). Frazier eventually obtained an injunction against his potential prosecution under these statutes on the grounds that it would violate his First Amendment rights. Frazier, 2007 U.S. LEXIS 72427, at *53-55.

131. Id. at $* 40$.

132. 2009 Legis. B. Hist. Cal. A.B. 585 (Bill Analysis, Assembly Floor), May 3, 2010 (emphasis added).

133. 2009 Legis. B. Hist. Cal. A.B. 585 (Bill Analysis, Senate Floor), April 23, 2010 (emphasis added). 
incompatible with privacy law. ${ }^{134}$

\section{B. Statutory Contradiction}

Motivational interests aside, California's right of publicity statutes are functionally designed to protect people's proprietary interests in the commercial value of their identities. ${ }^{135}$ It follows that individual recognition of these rights must depend on whether a person's identity possesses commercial value. ${ }^{136}$ Compounding interpretations of this commercial value requirement, set forth below, have established the prevailing view, at least academically, that all people-whether famous or anonymous-have rights of publicity in California's pre and post mortem context. ${ }^{137}$ But the statutory addition of per mortem protection renders this conclusion ripe for reconsideration.

\section{Pre Mortem Attachment}

Pre mortem right of publicity claimants generally have little trouble proving the commercial value of their identities. ${ }^{138}$ This is primarily because most section 3344 claims are brought by celebrities, ${ }^{139}$ who generally make a living exploiting their personalities in one way or another. ${ }^{140}$ Courts in California, however, have consistently voiced that non-celebrity claimants too are able to assert pre mortem right of publicity claims. ${ }^{141}$ The argument goes: "The appropriation of the identity of a relatively unknown person may result in

134. See supra Part II.A.1.

135. Lugosi v. Universal Pictures, 603 P.2d 425, 445 (Cal. 1979); Christoff v. Nestlé USA, Inc., 62 Cal. Rptr. 3d 122, 143 (Cal. Ct. App: 2007); Sinatra v. Nat'l Enquirer, Inc., 854 F.2d 1191, 1202 (9th Cir. 1988). "California has an overriding interest in safeguarding its citizens from the diminution in value of their names and likenesses, enhanced by California's status as the center of the entertainment industry." Id.

136. In the pre mortem context, the commercial value requirement is implied by the hybrid nature of section 3344. See supra Part III.A.1; Miller v. Collectors Universe, Inc., 72 Cal. Rptr. 3d 194, 207-08 (Cal. Ct. App. 2008); Christoff, 62 Cal. Rptr. 3d at 141 (citing Eastwood v. Superior Court, 198 Cal. Rptr. 342, 347 (Cal. Ct. App. 1983)). A claimant must prove economic injury in order to recover under the statute's right of publicity arm; otherwise the claimant effectively is limited to recovering statutory damages for invasion of privacy by commercial appropriation. Id. California's post mortem right of publicity statute explicitly requires a commercially valuable identity for the right's recognition. CAL. CIV. CODE $\S 3344.1(\mathrm{~h})$ (2009) amended by $2010 \mathrm{Cal}$. Stat. ch. $20, \S 1$.

137. See supra Parts III.B.1, B.2.

138. See 1 MCCARTHY, supra note 7, $\S \S 4: 2,4: 16$.

139. See Id.

140. The Celebrity 100, ForBEs.COM (June 28, 2010), http://www.forbes.com/lists/2010/ 53/celeb-100-10_The-Celebrity-100.html (ranking U.S. celebrities by categorical income).

141. Motschenbacher v. R.J. Reynolds Tobacco, Co., 498 F.2d 821, 824-25 n.11 (9th Cir. 1974); Dora v. Frontline Video, Inc., 15 Cal. App. 4th 536, 542 (1993); Knb Enters. v. Matthews, 78 Cal. App. 4th 362, 367 (2000); Christoff v. Nestlé USA, Inc., 62 Cal. Rptr. 3d 122, 143 (Cal. Ct. App. 2007). 
economic injury or may itself create economic value in what was previously valueless." ${ }^{142}$ Employing a principle native to trademark law, ${ }^{143}$ many commentators have interpreted this proposition to mean commercial value can be presumed from the defendant's unauthorized commercial use of a claimant's identity. ${ }^{144}$ Others have extended this presumption to conclude that all people have a pre mortem right of publicity ${ }^{145}$ as an innate right of personhood. ${ }^{146}$

\section{Post Mortem Attachment}

Commentators have similarly interpreted section 3344.1 as innately providing post mortem publicity rights to all people. ${ }^{147}$ The presumption of commercial value principle, however, has been much more contentious in this context. ${ }^{148}$ When the California Supreme Court first considered extending the right of publicity beyond a person's death, the court seemingly considered a person's pre mortem exploitation of his or her identity as a pre-requisite for post mortem protection. ${ }^{149}$ But as described above, ${ }^{150}$ the Lugosi majority was unclear as to whether "lifetime exploitation" was required for post mortem protection, or whether the court rejected the right of publicity's descendibility altogether. ${ }^{151}$

In overruling Lugosi and creating the statutorily descendible right of publicity, the California legislature only added to the Lugosi decision's

142. Christoff, 62 Cal. Rptr. 3d at 141 (citing Motschenbacher, 498 F.2d at 824-25 n.11); see 1 MCCARTHY, supra note 7, § 4:19-20.

143. See AMF Inc. v. Sleekcraft Boats, 599 F.2d 341, 354 (9th Cir. 1979). A defendant's intentional appropriation of a person's identity without their consent implies that the defendant believed that the identity was commercially valuable. 1 MCCARTHY, supra note $7, \S 4: 17$.

144. 1 MCCARTHY, supra note $7, \S 3: 2$. "Some damage to the commercial value of identity is presumed once it is proved that defendant has made an unpermitted use of some identifiable aspect of identity in such a commercial context that one can state that such damage is likely. If plaintiff seeks the recovery of damages, then the commercial damage must be proved and quantified." Id. Del Amo v. Baccash, 2008 WL 4414514, *6 (C.D. Cal. 2008). "[S]o long as a plaintiff has demonstrated (1) use of plaintiff's identity, (2) the appropriation of plaintiff's name or likeness to defendant's advantage, commercially or otherwise, and (3) a lack of consent, a plaintiff need not demonstrate injury." Id.

145. 1 MCCARTHY, supra note $7, \S \S 4: 19-20,6: 39$.

146. Id. $\S \S 1: 3,6: 39$. "[E]veryone's persona and identity has some 'commercial value' during life and at the time of death. That value may be large or small, but it cannot be said to be nonexistent, no matter how 'obscure' the person." Id. § 6:39.

147. Id.

148. 2 J. Thomas McCarthy, The Rights of Publicity and PrivaCy, $\$$ 9:11-15 (2d ed. 2010).

149. See supra Part II.B.3.

150. See id.

151. Lugosi v. Universal Pictures, 603 P.2d 425, 429 (Cal. 1979). "It seems to us rather novel to urge that because one's immediate ancestor did not exploit the flood of publicity and/or other evidence of public acceptance he received in his lifetime for commercial purposes, the opportunity to have done so is property which descends to his heirs." Id. 
ambiguity. ${ }^{152}$ Section 3344.1 provides post mortem protection for any person whose identity "has commercial value at the time of his or her death"; ${ }^{153}$ yet, the statute also states that post mortem protection exists "whether or not during [his or her] lifetime" the person used his or her identity for commercial purposes. ${ }^{154}$ Seemingly contradictory, California's post mortem right of publicity statute explicitly requires the existence of commercial value while rejecting the lifetime exploitation requirement.

Naturally, this contradiction has caused academic debate. ${ }^{155}$ Some commentators have viewed section 3344.1 as invalidating the commercial value presumption, ${ }^{156}$ concluding that every person must not have a descendible right of publicity. ${ }^{157}$ Others have interpreted the statute's language as broadening the right's post mortem scope. ${ }^{158}$ Those favoring an expansive view of section 3344.1 point to plausible reasons why a person might not exploit his her identity during life that have nothing to do with the non-existence of commercial value. ${ }^{159}$ To date, the California courts have not addressed section 3344.1's commercial exploitation ambiguity. The majority of commentators, however, continue to simply extend the commercial value presumption exercised under California's pre mortem right of publicity statute to its post mortem statutory counterpart. ${ }^{160}$ Again, the conclusion is that every person has a post mortem right of publicity as an innate right of personhood. ${ }^{16}$

\section{Per Mortem Attachment}

The notion that all people innately have pre and post mortem rights of

152. 1 MCCARTHY, supra note $7, \S 6: 39$.

153. CAL. CIV. CODE $\S 3344.1$ (h) (2009) (emphasis added), amended by $2010 \mathrm{Cal}$. Stat. ch. $20, \S 1$.

154. Id.

155. 1 MCCARTHY, supra note $7, \S 6: 39$.

156. Stephen F. Rohde, Dracula: Still Undead, 5 CAL. LAw. 51, 53 (April 1985).

157. Id.; see generally Peter L. Felcher \& Edward L. Rubin, Comment, The Descendibility of the Right of Publicity: Is There Commercial Life After Death?, 89 YALE L.J. 1125 (1980).

158. Evie K. Rubin, Note, Right of Publicity "Survives" in California: Cal. Civ. Code Section 990, 12 W. ST. U. L. REv. 299, 302 (1985); see generally Note, An Assessment of the Commercial Exploitation Requirement as a Limit on the Right of Publicity, 96 HARV. L. REV. 1703 (1983); see 2 MCCARTHY, supra note 148, § 9.14 n.12.

159. Rubin, supra note 158 , at 302 . These include "1) waiting until an appropriate medium for exploitation comes along, 2) personal sensitivities, 3) business judgment, 4) waiting until fame is at its peak, 50 death occurs before opportunity to exploit, 6) to specifically create a legacy for heirs, 7) where value could attach to name, likeness, etc. only after death, and 8) where the type of exploitation chosen might not be available during personality's lifetime." Id. at 302-03.

160. 1 MCCARTHY, supra note $7, \S 6: 39$ ("It is submitted that to read $\S 990(\mathrm{~h})(\S 3344.1(\mathrm{~h})$ ) as a sensible whole, it must be concluded that everyone's identity has 'commercial value' at the time of death.").

161. Id. 
publicity is compromised by the passage of $\mathrm{AB} 585$. Read within the state's three-piece statutory regime, the language of California's per mortem right of publicity statute necessarily implies that a commercially valuable identity is not an innate right of personhood. As amended by AB 585, section 3344.1 now defines "deceased personality" as any person whose identity "has commercial value at the time of his or her death, or because of his or her death . . ."162 This Note argues that California's addition of per mortem protection would have been unnecessary if every person's identity is truly considered to have an innate pre mortem commercial value, as all identities would thereby be considered commercially valuable at the time of death.

If credence is given to the established commercial value principles set forth above, something more than mere personhood but less than lifetime commercial exploitation is needed to endow an identity with commercial value. Presuming commercial value from a defendant's commercial use, this Note recognizes that any commercial use of a person's identity in the per mortem context necessarily occurs after that person's death. And because property rights transfer "on death," 63 a person whose identity is without commercial value at the time of death cannot be said to have transferred any property rights in that identity to his or her heirs. As such, California's per mortem publicity rights cannot be descendible-they are a posthumous creation.

\section{JUSTIFYING PUBLICITY-AS-PROPERTY}

Even assuming that per mortem economic injury is possible under California's statutory right of publicity regime and that it is indeed the injury sought to be remedied by $\mathrm{AB} 585$, a working policy justification eludes California's per mortem publicity-as-property model. This problem has "plagued the right of publicity" since its inception. ${ }^{164}$

\section{A. The Property Syllogism}

In endowing the right of publicity with the proprietary characteristic of assignability in Haelan Laboratories, Inc. ${ }^{165}$ Judge Frank adamantly dismissed the inquiry into whether the right should be labeled a form of "property" as well as whether it maintained any other traditional property characteristics. ${ }^{166}$ In a sentiment that was shared by several early commentators on the right of publicity, ${ }^{167}$ Judge Frank stated, "[T]he tag 'property' simply symbolizes the

162. CAL. CIv. Code $\S 3344.1$ (h) (2011) (emphasis added).

163. CAL. Prob. CODE $\S 5507$ (2010).

164. McKenna, supra note 9, at 247.

165. See supra Part II.B.2.

166. Haelan Labs., Inc. v. Topps Chewing Gum, Inc., 202 F.2d 866, 868 (2d Cir. 1953); see Westfall \& Landau, supra note 13, at 77-78.

167. William L. Prosser, Privacy, 48 CAL. L. REv. 383, 406 (1960). "It seems quite pointless 
fact that courts enforce a claim which has pecuniary worth."168

During the right of publicity's emerging years, courts in the United States remained hostile toward the right's development and largely followed Judge Frank's functionalist position. ${ }^{169}$ Commentators, however, quickly latched onto the label debate and continued to develop the notion of publicity-as-property. ${ }^{170}$ By the time California Civil Code section 990 was enacted in 1984, the right of publicity was widely considered a bona fide property right by courts and commentators alike. ${ }^{171}$ The statute explicitly adopts this trend by providing, "The rights recognized under this section are property rights, freely transferable or descendible ...."172

The right of publicity's expansion beyond Judge Frank's functional assignability was driven largely by a form of reasoning that commentators call the "property syllogism." that the right of publicity's assignability necessarily rendered it a form of property, many commentators jumped drastically to the conclusion that, because publicity is property, it must share all of the traditional characteristics of property, namely descendibility. ${ }^{175}$ This "formalistic" shift in reasoning has resulted in "a Frankenstein bearing little resemblance to [Judge Frank's] carefully considered functionalist purposes."176

The property syllogism was highly influential on the courts that initially considered the right of publicity's descendibility, ${ }^{177}$ and most court decisions that followed blindly applied the preceding courts' reasoning. ${ }^{178}$ Thus, a descendible right of publicity was created with little consideration given to any policy supporting it. ${ }^{179}$ And once most states codified the descendibility of their right of publicity, the property-based approach became an unshakable legal certainty. ${ }^{180}$

to dispute over whether such a right is to be classified as property." Id. (discussing the appropriation form of privacy invasion).

168. Haelan Labs., Inc., 202 F.2d at 868.

169. Westfall \& Landau, supra note 13 , at 80.

170. Id.

171. Id.

172. CAL. CIv. CoDE $\S 990$ (1988) (emphasis added), renumbered by 1999 Cal. Stat. ch. 998 , $\S 1$ (now codified at CAL. Civ. CoDE $\S 3344.1$ (2011)).

173. Westfall \& Landau, supra note 13 , at 74.

174. McKenna, supra note 9, at $245-46$. "There is nothing inherent in the notion of property that logically requires that all of the constitutive rights in the bundle be marshaled in favor of identity, and the law could easily provide only some, and even entirely different, protections." Id.

175. Westfall \& Landau, supra note 13 , at 83-84.

176. Id. at 123 .

177. Id. at $84-86$.

178. Id. at 87. "Many ... simply noted that descendibility had become the majority rule in American jurisdictions and therefore should be followed." Id.

179. Id.

180. Id. at $88-89$. 


\section{B. Theory and Policy}

Since the right of publicity's haphazard emergence as a form of intellectual property, courts and commentators have retrospectively attempted to justify exclusive ownership of the commercial value in identity according to traditional U.S. property theories. Although these approaches may be appropriate in isolated circumstances, none are suitable to comprehensively justify California's pre, post, and per mortem rights of publicity as property.

\section{Labor Theory}

The most common theoretical justification for granting exclusive property rights in identity is based on John Locke's natural rights labor theory. ${ }^{181}$ According to Locke, "When a person 'mixe[s]' his labor with a thing in its natural state, he 'join[s] to it something that is his own' and 'thereby makes it his property ...."'182 Courts and commentators have frequently justified the pre mortem right of publicity in this manner. ${ }^{183}$ Chief Justice Bird argued in his Lugosi dissent, "A celebrity must be considered to have invested his years of practice and competition in a public personality which eventually may reach marketable status. That identity ... is the fruit of his labors and is a type of property." "184 As a post mortem justification, Chief Justice Bird similarly claimed, "If the right is descendible, the individual is able to transfer the benefits of his labor to his immediate successors and is assured that control over the exercise of the right can be vested in a suitable beneficiary.",185

Although the labor theory justification for a property-based right of publicity is initially appealing, postmodern critics of the right have found it to be a gross oversimplification of the cultural process by which commercially valuable identities are created. ${ }^{186}$ Celebrities derive their economic value from their individual power "to carry and provoke meanings,"187 and "the media and the public always play a substantial part in the [meaning]-making process." 188 The media promote celebrities selectively, primarily through news and

181. Madow, supra note 12 , at 181 ; McKenna, supra note 9 , at 250.

182. Madow, supra note 12, at 175 n.239 (quoting JOHN LOCKE, THE SECOND TREATISE OF Government 17, 19 (Thomas P. Peardon ed., Bobbs-Merrill Co. 1952) (1690)).

183. Id. at 181 . "' $[\mathrm{A}]$ person who has 'long and laboriously nurtured the fruit of publicity values,' who has expended 'time, effort, skill, and even money' in their creation, is presumptively entitled to enjoy them himself.'" Id. (quoting Melville Nimmer, The Right of Publicity, 19 LAW \& CONTEMP. PROBS. 203, 216 (1954)).

184. Lugosi v. Universal Pictures, 603 P.2d 425, 441 n.17 (Cal. 1979) (citing Uhlaender v. Hendricksen, 316 F. Supp. 1277, 1282 (D. Minn. 1970)).

185. Id. at 446.

186. McKenna, supra note 9, at 252; Madow, supra note 12, at 181-82. "Fame is a 'relational' phenomenon, something that is conferred by others." Id. at 188.

187. Madow, supra note 12, at 185.

188. Id. at 193. 
advertising, based on their need to tell dramatic, compelling, and entertaining stories that capture and hold the public's attention. ${ }^{189}$ In turn, the public's reaction to or consumption of these personifications is what creates market value in particular identities. ${ }^{190}$ Therefore, no matter how much labor a person expends creating, monitoring, or shaping his or her image, the value of that person's identity always depends on whether the audience ultimately accepts it. ${ }^{191}$ Unlike with traditional labor, a celebrity cannot exclusively say, "I made it," of his or her commercially valuable identify, and as a result, any claim of exclusive entitlement to its associated economic value is unwarranted. ${ }^{192}$

The labor justification for publicity rights is even less persuasive when applied to posthumous identity protection. ${ }^{193}$ Whatever involvement a post mortem personality may have had in the creation of a valuable public image, the creative labor provided by that celebrity's heirs must have played a more tenuous role; ${ }^{194}$ otherwise, the celebrity's pre mortem labor-based claim would be further undermined. Additionally, this Note argues, a non-celebrity cannot be said to have expended time, effort, skill, and money in pursuit of the death that prompted his or her per mortem publicity value. And because the commercial value of a per mortem identity is necessarily created after death, ${ }^{195}$ the decedent is entirely removed from the meaning-making process.

\section{Unjust Enrichment}

The prevention of unjust enrichment is another common justification for the property-based right of publicity. ${ }^{196}$ As the inverse of the labor rationale, the focus of unjust enrichment theory is on the defendant's "free riding" rather than the claimant's just desserts. ${ }^{197}$ This theory was asserted for pre mortem publicity protection by the United States Supreme Court in Zacchini v. ScrippsHoward Broadcasting, the Court's only decision recognizing the right of publicity. ${ }^{198}$ There, the Court proposed that a defendant should not get for free

189. Id. at 190. As a case study of the media's influence on public perception, Michael Madow provides an interesting account of Albert Einstein's rise to fame in the United Statesfrom "mad scientist" to cultural icon. Id. at 185-88 (citing Marshall Missner, Why Einstein Became Famous in America, 15 Soc. STUD. SCI. 267 (1985)).

190. McKenna, supra note 9, at 254.

191. Madow, supra note 12, at 193-94.

192. Id. at 196.

193. Michael Decker, Note and Recent Development, Goodbye, Norma Jean: Marilyn Monroe and the Right of Publicity's Transformation at Death, 27 CARDOZO ARTS \& ENT. L.J. 243, 259 (2009).

194. Id.

195. See supra Part III.B.3.

196. McKenna, supra note 9, at 247-48; Madow, supra note 12, at 196.

197. McKenna, supra note 9 , at $247-48$.

198. Zacchini v. Scripps-Howard Broad. Co., 433 U.S. 562, 576-77 (1977). In Zacchini, the Court held that a television news broadcast of an entertainer's entire fifteen-second "human 
something of value from plaintiff for which the defendant would normally pay. ${ }^{199}$ In his Lugosi dissent, Chief Justice Bird similarly applied unjust enrichment theory in the post mortem context:

"There is no reason why, upon a celebrity's death, advertisers should receive a windfall in the form of freedom to use with impunity the name or likeness of the deceased celebrity who may have worked his or her entire life to attain celebrity status. The financial benefits of that labor should go to the celebrity's heirs ....,"200

But the application of unjust enrichment theory to California's propertybased right of publicity is yet another extension of the property syllogism; "it assumes an entitlement on behalf of the plaintiff to prove such an entitlement should exist. ${ }^{, 201}$ In order for a defendant's free riding to be unjust, a right of publicity claimant must first have exclusive moral entitlement to the commercial value of his or her personality. ${ }^{202}$ Without a working justification for the initial ownership, the unjust enrichment theory fails. ${ }^{203}$ Moreover, the post mortem right of publicity effectively authorizes the heirs of the deceased personality to free ride on that personality's economic value, regardless of the heirs' involvement in generating that value. ${ }^{204}$ For this same reason, unjust enrichment theory is an even more tenuous justification for per mortem personalities, who have even less of a moral claim, if any, to the commercial value of their identities.

\section{Economic Incentives}

Another policy justification asserted for pre mortem publicity rights is that exclusive ownership provides an economic incentive for artistic creation. ${ }^{205}$ Analogous to the primary theory behind copyright and patent law, ${ }^{206}$ this argument claims that pre mortem exclusivity incentivizes people to expend the time, money, and energy necessary to develop valuable identities that ultimately

cannonball" performance violated the entertainer's right of publicity. Id. at 578. The court rejected the broadcaster's First Amendment defense of newsworthiness. Id.

199. Id. at 576.

200. Lugosi v. Universal Pictures, 603 P.2d 425, 446 (quoting Note, The Right of Publicity Protection for Public Figures and Celebrities, 42 BROOKL,YN L. REV. 527, 547 (1976)).

201. McKenna, supra note 9, at 248

202. Id.

203. Id.

204. Decker, supra note 193, at 263.

205. Madow, supra note 12, at 206.

206. U.S. CONST. art. I, $\$ 8$ ("The Congress shall have Power ... To promote the Progress of Science and the useful Arts, by securing for limited Times to Authors and Inventors the exclusive Right to their respective Writings and Discoveries."). 
produce socially beneficial works. ${ }^{207}$ The United States Supreme Court also asserted this theory in Zacchini, ${ }^{208}$ as did Chief Justice Bird, dissenting in Lugosi:

[P]roviding legal protection for the economic value in one's identity against unauthorized commercial exploitation creates a powerful incentive for expending time and resources to develop the skills or achievements prerequisite to public recognition .... While the immediate beneficiaries are those who establish professions or identities which are commercially valuable, the products of their enterprise are often beneficial to society generally. ${ }^{209}$

Chief Justice Bird further alleged economic incentives as a justification for post mortem publicity protection, ${ }^{210}$ claiming the assurance that an individual's heirs will continue to benefit from the investment in publicity value provides additional encouragement for the individual to make such an investment. ${ }^{211}$

Critics of the economic incentives theory claim that it fails realistically to justify exclusive ownership of pre mortem publicity value. There is little evidence that modern celebrities would refuse to exercise their socially valuable talents or expertise without such ownership, ${ }^{212}$ and it is equally possible that the wealth generated by a celebrity's publicity rights disincentivizes further exercise of that celebrity's talents. ${ }^{213}$ Further, publicity value is a collateral source of income for most celebrities; thus, most would still be able to profit from the activities that generate their commercial value without exclusively exploiting their rights of publicity. ${ }^{214}$ This is unlike an author's copyright or an inventor's patent, which is much more necessary to secure a financial benefit in the author's or inventor's works. ${ }^{215}$

207. Madow, supra note 12, at 206.

208. Zacchini v. Scripps-Howard Broad. Co., 433 U.S. 562, 576 (1977). "[Publicity] protection provides an economic incentive for [a person] to make the investment required to produce a performance of interest to the public. This same consideration underlies the patent and copyright laws long enforced by this Court." $I d$.

209. Lugosi v. Universal Pictures, 603 P.2d 425, 441 (Cal. 1979) (citing Zacchini, 433 U.S. at 573).

210. Lugosi, 603 P.2d at 446. "[A]s with copyright protection, granting protection after death provides an increased incentive for the investment of resources in one's profession, which may augment the value of one's right of publicity." $I d$.

211. Id.; see Richard B. Hoffman, The Right of Publicity - Heirs' Right, Advertisers' Windfall, or Courts' Nightmare?, 31 DePAUL L. REV. 1,27-28(1981); Felcher \& Rubin, supra note 157 , at 1130 .

212. Madow, supra note 12, at 207; McKenna, supra note 9, at 261.

213. Madow, supra note 12, at 211-12.

214. Id. at 209.

215. Id. 
Economic incentives theory is even more unrealistic in the posthumous context. In all likelihood, the post mortem right of publicity has a disincentivizing effect on a celebrity's heirs. Allowing heirs to inherit exclusive property rights in a deceased celebrity's identity provides them with no incentive to develop their own talents or identities and to offer them for society's benefit. ${ }^{216}$ "[T] he celebrity already gathered fame and its attendant wealth, and the [heirs] may idly enjoy its benefits." ${ }^{217}$ Moreover, economic incentives completely fails to justify per mortem right of publicity protection. It is inconceivable that an individual can be incentivized to die, especially in any manner conceivably suitable for later commercial use. And it is unlikely that social and moral norms would tolerate a law that rewards such a practice. The per mortem context, therefore, allows a decedent no possibility of anticipating or reaping the potential benefits of his commercially valuable identity.

\section{IDENTITY APPROPRIATION IN GERMANY}

In response to the theoretical challenges asserted above, several commentators have recently proposed non-traditional, non-property justifications for the U.S. right of publicity. Notably, Kantian autonomy, as manifested through Germany's right of personality, has been suggested as an alternative rationale for protecting both the moral and economic interests people maintain in their identities. This Note extends this proposition as a means of reconciling California's pre, post, and per mortem rights of publicity.

\section{A. The Right of Personality}

German identity protection is comprised of statutory rights in a person's name and image and a judicially created general right of personality ${ }^{218}$ Most judgments concerning unauthorized identity appropriation arise under the specific statutes; ${ }^{219}$ however, when they prove inapplicable or insufficient, the general right of personality serves as a "catch-all" or "gap filler" for other appropriation of identity claims. ${ }^{220}$

\section{The Right to Image}

Section 22 of Germany's Law on Artistic Creations (KUG) recognizes

216. Decker, supra note 193, at 263.

217. Id.

218. 1 MCCARTHY, supra note 7, § 6:163.

219. Ellen S. Bass, Comment, $A$ Right in Search of a Coherent Rationale - Conceptualizing Persona in a Comparative Context: The United States Right of Publicity and German Personality Rights, 42 U.S.F. L. REV. 799, 829 (2008).

220. Id. at 831; Susanne Bergmann, Publicity Rights in the United States and in Germany: A Comparative Analysis, 19 LOY. L.A. ENr. L. REv. 479, 503 (1999). 
the right to one's image. ${ }^{221}$ It provides that a person's picture "may only be circulated or displayed with the consent of the [person] pictured."222 Section 22 KUG also provides for post mortem protection, stating, "After the death of the [person] pictured the consent of his relatives is required up to the expiration of [ten] years." ${ }^{223}$ A claim under $22 \mathrm{KUG}$ requires that the depicted person be recognizable from the unauthorized portrayal, ${ }^{224}$ but recognition is not limited to the individual's face. ${ }^{225}$ Likeness has also been found in characteristic features, including clothing, hairstyle, gestures, silhouette, and backside. ${ }^{226}$ Further, German courts and commentators define the term "picture" broadly, covering "all techniques and types for displaying a person.",227

\section{The Right to Name}

Section 12 of the German Civil Code (BGB) prohibits unauthorized use of another person's name. ${ }^{228}$ It provides, "if the rights of the person entitled to use a name [are] injured because of another's unauthorized use of the same name, the person entitled to use the name has the right to claim to restrain disturbance by the other person. ${ }^{229}$ The right to one's name includes an individual's surname and family name, as well as publicly known stage names, pseudonyms, and nicknames. ${ }^{230}$ An action arises under section 12 BGB only if "the use of the name causes a likelihood of confusion among the public.,"231 If there is no such likelihood of confusion, as is likely the case with most noncelebrities, the general right to personality provides supplementary protection for the right to name. ${ }^{232}$ Germany's Federal Supreme Court has held the right to name to be inalienable and not descendible. ${ }^{233}$ The general right of personality, however, provides supplementary protection in this regard as well. ${ }^{234}$

221. Kunsturhebergesetz [KUG] [Law on Artistic Creations], 1907, BUNDESGESETZBLATT, Teil III [BGBL. III] $\S 22$ (Ger.), translated in 1 MCCARTHY, supra note 7, § 6:172.

222. Id.

223. Id. ("Relatives in terms of this Act are his surviving spouse and children, or failing these, the parents.").

224. 1 MCCARTHY, supra note $7, \S 6: 164$.

225. Id.

226. Bergmann, supra note 220 , at 504.

227. 1 MCCARTHY, supra note $7, \S 6: 164$.

228. BÜRGERLICHES GESETZBUCH [BGB] [Civil Code], 1900, REIChGESETZBLATT, Teil II

[RGBL. II] § 12, translated in 1 MCCARTHY, supra note 7, § 6:172.

229. Id.

230. 1 MCCARTHY, supra note $7, \S 6: 165$.

231. Id.; see Bergmann, supra note 220 , at 511 .

232. 1 MCCARTHY, supra note 7, § 6:165.

233. EUROPEAN TORT AND INSURANCE LAW YEARBOOK: EUROPEAN TORT LAW 2007 291-92

(Helmut Koziol \& Barbara C. Steininger, eds., 2007).

234. Id. 


\section{The General Right of Personality}

In 1954 the Federal Supreme Court created supplemental protection for the rights to name and image by recognizing a "general right of personality."235 This right protects against all other infringements of an individual's personality. ${ }^{236}$ The Court has established no conclusive definition of the right; rather, its scope is determined on a case-by-case basis. ${ }^{237}$ Factual circumstances in which the general right of personality has been applied include intrusion into the private sphere; the publication of personal information; defamation; portrayal in false light; and most importantly, for the purposes of this Note, unauthorized commercial appropriation. ${ }^{238}$ German courts have employed the inter-related concepts of dignity, autonomy, and self-determination in varying degrees to justify the scope of personality rights within these particular contexts. $^{239}$

\section{B. Theory and Policy}

Unlike the U.S. right of publicity, Germany's right of personality is not an intellectual property right; it is a personal right grounded in the country's constitutional guarantee of human dignity. ${ }^{240}$ Drafted amid national defeat and humiliation following the collapse of the Third Reich in $1945,{ }^{241}$ the German Constitution (Basic Law) reflects a "conscious intention to elevate modern Germany beyond the inhumanity of Naziism ...."242 This is evident in Article 1(1), which states emphatically, "Human dignity shall be inviolable.,243 Article 1(2) strengthens this guarantee by emphasizing human rights as dignity's practical focus. ${ }^{244}$ It provides, "The German people therefore acknowledge inviolable and inalienable human rights as the basis of every community, of peace and of justice in the world. ${ }^{, 245}$ With human dignity at its core, the Basic Law establishes a constitutional order for Germany in which human values "are

235. Bass, supra note 219 , at 830 .

236. Id.

237. Bergmann, supra note 220, at 502.

238. Huw Beverley-Smith et al., Privacy, Property and Personality: Civil Law Perspectives on COMMERCIAL APPROPRIation 114-15 (2005).

239. Id. at 114-19.

240. Bass, supra note 219 , at 828-29.

241. Ernst Benda, The Protection of Human Dignity (Article l of the Basic Law), 53 SMUL. REV. 443, 445 (2000).

242. Edward J. Eberle, Human Dignity, Privacy, and Personality in German and American Constitutional Law, 1997 UTAH L. REV. 963, 971 (1997).

243. GRUNDGESETZ FÜR DIE BUNDESREPUBLIK DEUTSCHLAND [GRUNDGESETZ] [GG] [BASIC LAW], May 23, 1949, BGBl. I, art. 1(1) (Ger), translated in EBERLE, DiGNITY AND LIBERTY: CONSTITUTIONAL Visions IN GERMANY AND THE United STATES, app. B (2002).

244. Eberle, supra note 242, at 971.

245. GRUNDGESETZ [GG] [BASIC LAw], May 23, 1949, BGBl. I, art. 1(2) (Ger), translated in EBERLE, supra note 243, app. B. 
not to be sacrificed for the exigencies of the day," as had occurred under the Nazi regime. ${ }^{246}$

"The concept of human dignity in the Basic Law reflects the influence of ... Christian natural law, Kantian moral philosophy, and more individualistic, or existential, theories of personal autonomy and self-determination.,"247 Although its drafters did not intend for the Basic Law to be strictly associated with any one of these philosophies, ${ }^{248}$ Germany's Federal Constitutional Court has mainly followed Immanuel Kant's theory of moral autonomy in interpreting dignity's meaning. ${ }^{249}$

\section{Kantian Autonomy}

Kantian moral and political philosophy is founded on Kant's conception of human dignity. ${ }^{250}$ Kant viewed dignity as deriving from the innate freedom required to exercise human reason in pursuit of autonomy, ${ }^{251}$ with moral autonomy being "the highest goal of organized society." ${ }^{252}$ Kantian autonomy, therefore, is considered the "universal" and "unconditional" human capacity for moral legislation. ${ }^{253}$ It is self-governance, "free from moral determinism, and not motivated by sensuous desires." ${ }^{254}$ Simplified, moral autonomy reflects the process of choosing that which is good because it is good. ${ }^{255}$

Under this model, people can self-legislate only if they are free from external constraints. ${ }^{256}$ Therefore, individual liberty must presuppose autonomy. ${ }^{257}$ According to Kant, liberty is the "'one sole and original right that belongs to every human being by virtue of his humanity,' and it comprises 'the attribute of a human being's being his own master." ${ }^{258}$ Outside interference with one's person necessarily violates this innate right, and as such, autonomy

246. EBERLE, supra note 243, at 19; see Eberle, supra note 242, at 967 .

247. EBERLE, supra note 243, at 42-43. "Under Christian natural law theories, dignity is a gift from God and, therefore, an inalienable aspect of humanity, beyond human tampering." Id. at 43. "[The third] theory seems the one most in accord with American views, notably present in free-speech law." Id.

248. Id. at 42 .

249. Id. at 43 .

250. Immanuel Kant, The Metaphysical Elements of Justice: Part I of the METAPHYSICS OF MORALS, ix (John Ladd trans. 1965) (1797).

251. Haemmerli, supra note 13, at 415-16.

252. McKenna, supra note 9 , at 276 n.217.

253. Kim Treiger-Bar-Am, Kant on Copyright: Rights of Transformative Authorship, 25 CARDOZO ARTS \& ENT. L.J. 1059, 1097 (2008).

254. Id. at 1095.

255. H.J. Paton, The Moral LaW 60 (1947).

256. KANT, supra note 250 , xi; Haemmerli, supra note 13 , at 414-15. Kant refers to liberty, freedom from external constraints, as "negative freedom," and autonomy, freedom from internal constraints, as "positive freedom." Id.

257. KANT, supra note 250 , xi.

258. Haemmerli, supra note 13, at 414 (quoting KaNT, supra note 250 , at 44 ). 
requires that humans be treated "always as ends in themselves [and] never as means.",259

\section{Moral Self-Determination}

Further rooted in Kantian conceptions of dignity and autonomy is Article 2(1) of the Basic Law, which provides, "Everyone shall have the right to the free development of his personality . . . ${ }^{, 260}$ This constitutional principle facilitates the full development within society of everyone's individual capabilities, allowing all people to realize their inner persons. ${ }^{261}$ For Kant, the development of the inner self is a right of moral-self determination, as is illustrated by Kant's view of authorial expression. ${ }^{262}$

Kant considered an author's expression to be "an action of the will," a continuation of the author's inner self. ${ }^{263}$ As such, a human being is considered to have a "'natural purposiveness' . . . to fulfill the speaker's capacity to 'communicate his thoughts.",264 An author's right in his communicative acts is therefore an innate right of self-ownership. ${ }^{265}$ In this sense, only the author may decide to disclose his or her work and in what form such disclosure will occur. ${ }^{266}$ The dissemination of an author's words without consent forces the author to speak against his or her will and is a violation of the author's freedom and autonomy. ${ }^{267}$

\section{Economic Self-Determination}

Kant's conception of authorial rights has found expression in German Copyright Law. ${ }^{268}$ German copyright protects both an author's personal interest in his work and his commercial interest in the exploitation of that work. ${ }^{269}$ As a

259. Eberle, supra note 242 , at 974 .

260. GRUNDGESETZ [GG] [BASIC LAW], May 23, 1949, BGBl. I, art. 2(1)(Ger), translated in EBERLE, supra note 243, at app. B.

261. Edward J. Eberle, The German Idea of Freedom, 10 OR. REV. INT'L L. 1, 23 (2008).

262. Treiger-Bar-Am, supra note 253, at 1073.

263. Bass, supra note 219 , at 836 .

264. Treiger-Bar-Am, supra note 253, at 1076 (quoting IMMANUEL KANT, THE METAPHYSICS OF MORALS 182 (Mary Gregor ed., 1996) (1797)).

265. Bass, supra note 219 , at 836.

266. Neil Netanel, Copyright Alienability Restrictions and the Enhancement of Author Autonomy: A Normative Evaluation, 24 RUTGERS L.J. 347, 375 (1993).

267. Id. at $374-75$; Bass, supra note 219 , at 836 .

268. Netanel, supra note 266, at 378-79. Kant's conception of author's rights is reflected in the monist school of copyright theory, which was adopted by the German Copyright Act. Id.; see generally Urheberrechtsgesetz [UrhG] [Copyright Law], 1965, BUNDESGESETZBLATT, Teil I [BGBL. I]. The monist theory views authorial rights as a "fundamentally personal right to determine when, in what form, and for what purpose his creative work is to be communicated to the public." Bass, supra note 219 , at 833 .

269. Netanel, supra note 266, at 379. 
personality right, copyright is part of an author's ownership of the inner-self, and "economic interests are necessarily subsumed within [this] personal sphere." 270 This Note refers to the latter principle as "economic selfdetermination.,"271

Significantly, for the purposes of this Note, German courts have interpreted $22 \mathrm{KUG}$, the right to image, in accordance with these German copyright principles. ${ }^{272}$ "Just as the author has the inherent right to determine the communication of the author's thoughts to the public, the individual has the inherent right to determine whether and how his image will be displayed in the world. ${ }^{273}$ In this light, 22 KUG constitutes a hybrid right, protecting both the moral and the economic interests in a person's image. ${ }^{274}$

\section{Commercial Appropriation Cases}

The suitability of Kantian autonomy as an alternative, reconciliatory approach to California's property-based rights of publicity is evident in Germany's application of the right of personality in commercial appropriation cases. There, German courts have generalized the principle of economic selfdetermination to extend $22 \mathrm{KUG}$ 's hybrid protection to the general right of personality. ${ }^{275}$ As is illustrated by the case law below, this broad application allows for an assignable and descendible commercial interest in a person's identity, similar to the U.S. right of publicity. It also affords posthumous protection of a person's moral interests against unauthorized commercial appropriation, comparable to the privacy motives of $\mathrm{AB} 585$.

\section{Assignable Economic Interests}

In the case of Nena, a merchandising company brought suit to recover a licensing fee from a manufacturer of products featuring the likeness of a German singer performing under the stage name, "Nena." ${ }^{276}$ The merchandising

270. Bass, supra note 219 , at 833.

271. See Alice Farmer, Towards a Meaningful Rebirth of Economic Self-Determination: Human Rights Realization in Resource-Rich Countries, 39 N.Y.U. J. INT'L L. \& PoL. 417, 418 (2006) (defining "economic self-determination" politically as "a people's capacity to dispose freely of natural resources in accordance with democratically-taken decisions). See infra note 276.

272. Bass, supra note 219 , at 833 .

273. Id. at 836 .

274. Id. at 833 .

275. BEVERLY-SMITH ET AL., supra note 238, at 118. "It is well established that . . the general personality right grants a right of self-determination concerning the commercial use of all aspects of personality." Id.

276. Bundesgerichtshof [BGH] [Federal Court of Justice] October 14, 1986, VI ZR 10/86 (Nena), translated in 19 INT'L REV. INDUS. PROP. \& COPYRIGHT L. 269 (1988). "The plaintiff claims that the licensing fees range between DM 5,000 and DM 20,000." Id. at 270. 
company had an exclusive license to use all of Nena's "commercially exploitable rights, including the right to her own likeness, ${ }^{, 277}$ which the manufacturer did not have consent to use. ${ }^{278}$ In its defense, the manufacturer claimed that, "as an extension of the general personality right," the right to image is inalienable. ${ }^{279}$ The Federal Supreme Court agreed, but concluded that the merchandising company was entitled to recover a fee regardless. ${ }^{280}$ The Court stated,

[T] he plaintiff's claim is not ... defeated by the fact that the contract . . . due to the nonassignability of the right in one's own likeness, did not confer rights upon the plaintiff, which the plaintiff could claim against third parties in its own name. At issue here is not the right to an injunction order but the right to recover a fee which plaintiff demands for the commercial exploitation of the vocalist Nena's likeness. The decision whether to award this recovery does not require a decision on the controversial question of whether or not the right to one's own likeness, due to its legal nature as a general personality right, is transferable. The defendant's use of Nena's likeness gave rise to the plaintiff's right to recover the usual fee for permission to utilize the likeness ... and does not require that Nena's right in her own likeness had been transferred to the plaintiff. ${ }^{281}$

\section{Descendible Economic Interests}

In the case of Marlene Dietrich, a theater production company authorized the use of Marlene Dietrich's name and image in conjunction with the sale of automobiles, cosmetics, and other merchandise to promote the company's musical on the life of the late actress. ${ }^{282}$ Dietrich's sole heir sought an injunction against and compensation for this commercial use, claiming posthumous infringement of Marlene's personality rights. ${ }^{283}$ The company argued that posthumous personality rights protected only the non-material

277. Id. at $260-70$.

278. Id.

279. Id.

280. Id. at 271 .

281. Id.

282. Bundesgerichtshof [BGH] [Federal Court of Justice] December 1, 1999, 1 ZP 49/97 (Marlene Dietrich), translated at http://www.utexas.edu/law/academics/centers/ transnational/work_new/german/case.php?id=726.

283. Id. 
interests of the deceased, but the Federal Supreme Court disagreed ${ }^{284}$ Based on the recognized ability to exploit one's personality during life, the Court concluded that the inheritability of the elements of the right of personality having financial value was necessary to protect those same interests after death: $:^{285}$

An effective posthumous protection of the elements of the right of personality which are of financial value is only guaranteed if the heir can step into the role of the holder of the right of personality and can, in defending the presumed interests of the deceased, proceed in the same way as that person could have done against an unauthorised exploitation. $^{286}$

\section{Posthumous Moral Interests}

In the case of Heinz Erhardt, the son of a well-known comedian sought an injunction against, not compensation for, the posthumous use of his deceased father's voice imitation in a radio advertisement. ${ }^{287}$ The Hamburg Court of Appeals (OLG Hamburg) held that "an artist's personality could not be subjected to commercial exploitation immediately after his death" because of the deceased's "claim to dignity" and "the necessity to reserve the commercial exploitation to the artist's heirs." ${ }^{288}$ The court emphasized that, because the general right of personality would have protected Erhardt's likeness during life, it would be constitutionally unacceptable if his personality could be freely imitated immediately after his death. ${ }^{289}$ This holds true "regardless of whether the imitation compromises the dignity and integrity of a person or their heir's right of exploitation. $\$ 290$

\section{RECOMMENDATIONS}

This Note advocates California's adoption of a personality rights regime as a means of reconciling the compounding disparities among the state's current pre, post, and per mortem right of publicity statutes. The German cases

284. Id.

285. Id.

286. Id.

287. OBERLANDESGERICHT HAMBURg [OLG HAMBURG] [Hamburg Court of Appeals] May 8, 1989, 3 W 45/89 (Heinz Erhardt), translated in 21 INT'L REV. INDUS. PROP. \& COPYRIGHT L. 881 (1990).

288. Id. at 882 .

289. Id. at 881 .

290. Id. 
discussed above illustrate how the application of economic self-determination can serve as a comprehensive theoretical justification for California's statutory rights of publicity, which have proven incompatible with its property-based regime. ${ }^{291}$ Economic self-determination accounts for the alienability and descendibility characteristics that have come to define California's pre and post mortem rights of publicity, ${ }^{292}$ while simultaneously providing for the personal, posthumous interests served by the state's pre mortem protection. ${ }^{293}$ Thus, individuals in California would be able to recover profits for the unauthorized use of their commercially valuable identities, but commercial value would not be a pre-requisite for all posthumous protection. ${ }^{294}$ Moreover, economic selfdetermination rationalizes the prevailing principle that all people have a right of publicity as an innate characteristic of personhood, ${ }^{295}$ which better addresses the critiques of granting exclusive ownership in the cultural product of fame. ${ }^{296}$

Admittedly, the Kantian foundation of Germany's right of personality does not exactly square-up with the law of the United States. ${ }^{297}$ Although both U.S. and German law rest on the duality of liberty and autonomy, ${ }^{298}$ in the United States, there is no designated moral value organizing this selfgovernance. ${ }^{299}$ "Americans [instead] see themselves as autonomous people who themselves determine the norms and values that infuse the social order." ${ }^{, 300} \mathrm{But}$ despite this disparity, personality ideals are not entirely unrecognized in the United States, ${ }^{301}$ especially in California.

Over the last thirty years, moral rights ${ }^{302}$ legislation has emerged in the United States as a form of limited personality protection. ${ }^{303}$ As historically found in European law, this bundle of rights protects an artist's interest in his or her work as an expression of the artist's personality and the foundation of his or her artistic reputation. ${ }^{304}$ In order to protect this reputation, an artist is typically

291. See supra Parts III, IV.

292. See supra Parts V.C.1, 2.

293. See supra Part V.C.3.

294. See supra Part III.A.

295. See id.

296. See supra Part IV.B.

297. EBERLE, supra note 243, at 127. German autonomy law is focused on dignity, not privacy. Id.

298. Id. at 131.

299. Id. at $47-48,131$. There is no reference to dignity in the U.S. Constitution. Id. at 47.

300. Id. at 48 .

301. Id. at 47. "Instead, the idea of dignity and personality must be implied from the promise of liberty in the due process clause or other textual authority." Id. "The self-realization component to dignity is well represented in American law, especially in substantive due process and free speech law." Id. at 46.

302. "The most popular name identifying this bundle of personal rights is the French term droit moral, loosely translated as 'moral rights."' John G. Petrovich, Artists' Statutory Droit Moral in California: A Critical Appraisal, 15 LoY. L.A. ENT. L. Rev. 29, 29 (1981).

303. See CAL. Civ. CoDe $\S 987$ (2010).

304. Petrovich, supra note 302, at 29. 
granted the rights to creation, disclosure, paternity, and integrity in his or her work. $^{305}$

In 1981 the California legislature enacted the California Art Preservation $A c t,{ }^{306}$ statutorily recognizing the moral rights of artists in certain visual arts. ${ }^{307}$ Notably, subsection (a) of the Act states, "The Legislature hereby finds and declares that the physical alteration or destruction of fine art, which is an expression of the artist's personality, is detrimental to the artist's reputation, and artists therefore have an interest in protecting their works of fine art against any alteration or destruction. ${ }^{, 308}$ Although the Act only provides for the rights of paternity ${ }^{309}$ and integrity, ${ }^{310}$ it is speculated that the right of disclosure was omitted due to legislative concerns over federal copyright preemption. ${ }^{311}$

An infringement of an artist's moral rights under the Act entitles the artist to injunctive relief, actual and punitive damages, reasonable attorneys' and expert witness fees, and "any other relief which the court deems proper."312 More importantly, for the purposes of this Note, the Act provides for posthumous protection of these personal interests. ${ }^{313}$ Subsection (g) of the Act states, "The rights and duties created under this section: (1) Shall, with respect to the artist, or if any artist is deceased, his or her heir, beneficiary, devisee, or personal representative, exist until the 50th anniversary of the death of the artist." $" 314$

This Note does not suggest that the proposed personality-based identity protection is capable of integration with California's moral rights law. Rather, this law illustrates California's recognition of personality rights as a means of protecting a person's innate interest in the moral and economic selfdetermination of his or her personality — both during life and after death.

305. Id.

306. 1979 Cal. Stat. ch. $409, \S 1$.

307. Petrovich, supra note 302 , at 30 ("California [was] the first state to provide specific statutory protection for the moral rights of visual artists.").

308. CAL. CIV. CODE $\S 987$ (a) (2010) (emphasis added). “'Fine art' means an original painting, sculpture, or drawing, or an original work of art in glass, of recognized quality, but shall not include work prepared under contract for commercial use by its purchaser." Id. $\S$ 987(b)(2).

309. Id. $\S 987$ (d) ("The artist shall retain at all times the right to claim authorship, or, for a just and valid reason, to disclaim authorship of his or her work of fine art.").

310. Id. $\S 987$ (c)(1) ("No person, except an artist who owns and possesses a work of fine art which the artist has created, shall intentionally commit, or authorize the intentional commission of, any physical defacement, mutilation, alteration, or destruction of a work of fine art.").

311. Peter H. Karlen, Moral Rights in California, 19 SAN Diego L. Rev. 675, 685 (1982).

312. CAL. Crv. CoDE $\S 987$ (e) (2010).

313. Id. $\S 987(\mathrm{~g})$.

314. Id. 


\section{CONCLUSION}

California's per mortem right of publicity compromises the state's preexisting publicity-as-property statutory regime. $\mathrm{AB} 585$ was motivated by the emotional concerns found at the heart of privacy law, and its ability to address the economic injuries that define publicity rights is incompatible with the commercial value principles of California's pre and post mortem statutes. Moreover, the state's pre mortem protection overextends the theoretical justifications commonly purported for the state's property-based publicity rights. Germany's right of personality, however, presents a comparative model for reconciling California's incompatible right of publicity statutes. As justified by the Kantian-inspired theory of economic self-determination, the right of personality accounts for an assignable and descendible identity without requiring economic value or emotional injury. In this regard, California's protection against commercial appropriation could rightfully be considered an innate right of personhood. 
